\title{
Differences in the soil bacterial community under organic farming and conventional farming modes revealed by $16 \mathrm{~S}$ rDNA sequencing
}

Research article

Keywords:

Posted Date: December 21st, 2020

DOl: https://doi.org/10.21203/rs.3.rs-21660/v2

License: (c) (i) This work is licensed under a Creative Commons Attribution 4.0 International License.

Read Full License

Version of Record: A version of this preprint was published at Journal of Biobased Materials and Bioenergy on February 1st, 2021. See the published version at https://doi.org/10.1166/jbmb.2021.2027. 


\section{Abstract}

The authors have requested that this preprint be withdrawn due to erroneous posting.

\section{Full Text}

The authors have withdrawn this preprint from Research Square. 